Bull. Chem. Soc. Ethiop. 2013, 27(3), 405-411.

ISSN 1011-3924

Printed in Ethiopia

DOI: http://dx.doi.org/10.4314/bcse.v27i3.9

(c) 2013 Chemical Society of Ethiopia

\title{
SYNTHESIS AND X-RAY STUDIES OF RUTHENIUM(II) COMPLEXES CONTAINING HYDRAZINE AND BENZYL ISOCYANIDE LIGANDS
}

\author{
Samson O. Owalude ${ }^{1,4^{*}}$, Ezekiel O. Odebunmi ${ }^{1}$, Uche B. Eke ${ }^{1}$, Reinout Meijboom ${ }^{2}$, Vladimir N. \\ Nesterov $^{3}$, Eric Singleton ${ }^{2}$ and Neil J. Coville ${ }^{4}$ \\ ${ }^{1}$ Department of Chemistry, University of Ilorin, P.M.B. 1515, Ilorin, Nigeria \\ ${ }^{2}$ Department of Chemistry, University of Johannesburg, Auckland Park 2006, Johannesburg, \\ South Africa \\ ${ }^{3}$ Department of Chemistry, University of North Texas, 1155 Union Circle, \#305070 Denton, TX \\ 76203-5017, USA \\ ${ }^{4}$ Molecular Sciences Institute, School of Chemistry, University of the Witwatersrand, \\ Johannesburg 2050, South Africa
}

(Received December 20, 2012; revised July 24, 2013)

\begin{abstract}
The reaction of the polymeric species $\left[\left\{\mathrm{RuCl}_{2}(\mathrm{COD})\right\}_{\mathrm{x}}\right](\mathbf{1} ; \mathrm{x}>2 ; \mathrm{COD}=$ cyclo-octa-1,5-diene $)$ and hydrazine hydrate in methanol under reflux gave a pale pink solution from which the salt $\left[\mathrm{Ru}(\mathrm{COD})\left(\mathrm{N}_{2} \mathrm{H}_{4}\right)_{4}\right]\left[\mathrm{BPh}_{4}\right]_{2} \cdot \mathrm{CH}_{3} \mathrm{OH}(\mathbf{2})$ was isolated on addition of $\mathrm{NaBPh}_{4}$. Treatment of 2 in refluxing acetone in the presence of the ligand benzyl isocyanide give a complex of stoichiometry $\left[\mathrm{Ru}\left(\mathrm{NH}_{2} \mathrm{~N}=\mathrm{CMe}_{2}\right)_{2}\left(\mathrm{PhCH}_{2} \mathrm{NC}\right)_{4}\right]\left[\mathrm{BPh}_{4}\right]_{2}(3)$ on the substitution of the labile COD ligand. The two compounds have been characterized by elemental analyses, IR and NMR measurements and single-crystal X-ray diffraction studies. The ruthenium in both compounds has a distorted octahedral coordination geometry.
\end{abstract}

KEY WORDS: Cycloocta-1,5-diene, Hydrazine hydrate, Isocyanide, Ruthenium

\section{INTRODUCTION}

The coordination chemistry of $\eta^{4}$-diene type ligands such as 1,5-cyclooctadiene (COD) and 2,5norbornadiene (NBD) relies on their ability to act as labile ligands [1]. While the COD could bind to a metal via one $\left(\eta^{2}\right)$ or two $\left(\eta^{4}\right)$ of its double bonds it generally binds as an $\eta^{4}$ ligand. The polymeric compound $\left[\left\{\mathrm{RuCl}_{2}(\mathrm{COD})_{\mathrm{x}}\right\}\right]$ has attracted particular attention due to the lability of the $\eta^{4}$-coordinated COD ligands, which are able to undergo exchange reactions under very mild conditions [2]. This unique property has been widely applied in numerous ligand exchange processes, making the polymer an ideal precursor for the synthesis of an extensive range of active ruthenium(II) compounds [3-6].

There is continued interest in the study of the chemistry of transition metal complexes containing hydrazine $\left(\mathrm{NH}_{2} \mathrm{NH}_{2}\right)$ or substituted hydrazine $\left(\mathrm{RNHNH}_{2}\right)$ as ligands. This is partly due to the interest in different coordination modes offered by hydrazine complexes [7-10] and also to the importance of hydrazine in the dinitrogen fixation process [11]. The coordination of hydrazine to metal centers is usually through the nitrogen in a monodentate fashion but in a few cases, a bridging bidentate coordination mode can be adopted [11]. To accurately determine the mode of coordination in these complexes, X-ray crystallographic analysis is required.

In previous reports, anhydrous hydrazine and substituted hydrazine were used to prepare the hydrazine complexes $[3,12]$. Anhydrous hydrazine is a highly regulated product; the use of

*Corresponding author. E-mail: owalude1412@yahoo.com; owalude@unilorin.edu.ng 
hydrated hydrazine was therefore investigated. We have hence prepared the complex $\left[\mathrm{Ru}(\mathrm{COD})\left(\mathrm{N}_{2} \mathrm{H}_{4}\right)_{4}\right]\left[\mathrm{BPh}_{4}\right]_{2}(2)$ through the reaction of polymeric species $\left[\left\{\mathrm{RuCl}_{2}(\mathrm{COD})\right\}_{\mathrm{x}}\right](\mathbf{1}$ $\mathrm{COD}=$ cyclo-octa-1,5-diene) and hydrazine hydrate in methanol. Subsequent reaction of 2 in refluxing acetone with benzyl isocyanide produced $\left[\mathrm{Ru}\left(\mathrm{NH}_{2} \mathrm{~N}=\mathrm{CMe}_{2}\right)_{2}\left(\mathrm{PhCH}_{2} \mathrm{NC}\right)_{4}\right]\left[\mathrm{BPh}_{4}\right]_{2}(3)$. Our studies showed that the hydrated hydrazine, a commercially available reagent, can be used to prepare the $\mathrm{Ru}(\mathrm{II})$-hydrazine complexes. The structures of the two complexes were determined using single crystal X-ray diffraction analysis.

\section{EXPERIMENTAL}

\section{General procedures}

The starting material [ $\left.\left\{\mathrm{RuCl}_{2}(\mathrm{COD})\right\}_{\mathrm{x}}\right] \mathbf{1}$ was prepared as described previously [4]. Hydrazine hydrate was obtained commercially from SAARCHEM (PTY) LTD, South Africa and was not further purified, while benzyl isocyanide was purchased from Sigma-Aldrich. The reactions involving benzyl isocyanide were carried out under a purified nitrogen atmosphere using standard Schlenk techniques while all other reactions were performed in air. Melting points were obtained on a Kofler hot-stage apparatus and were uncorrected. Infrared spectra of both compounds were recorded in the solid state (ATR) on a Bruker Tensor 27 FTIR spectrophotometer. The ${ }^{1} \mathrm{H}$ and ${ }^{13} \mathrm{C}\left\{{ }^{1} \mathrm{H}\right\}$ NMR NMR spectra of 2 were recorded on a Bruker DRX 250 spectrometer while that of $\mathbf{3}$ was recorded on a Bruker $300 \mathrm{MHz}$ instrument at $298 \mathrm{~K}$. The ${ }^{1} \mathrm{H}$ and ${ }^{13} \mathrm{C}\left\{{ }^{1} \mathrm{H}\right\}$ chemical shifts were calibrated to solvent peaks, which are reported relative to TMS. Microanalyses were carried out at the Center for Nanotechnology, Department of Chemistry, Rhodes University, South Africa.

Synthesis of (cycloocta-1,5-diene)tetrakis(hydrazine)ruthenium bis(tetraphenylborate).methanol $\left[\mathrm{Ru}(\mathrm{COD})\left(\mathrm{N}_{2} \mathrm{H}_{4}\right)_{4}\right]\left(\mathrm{BPh}_{4}\right)_{2} \cdot \mathrm{CH}_{3} \mathrm{OH}(2)$

The hydrazine complex was prepared from the polymer $\left[\left\{\mathrm{RuCl}_{2}(\mathrm{COD})\right\}_{\mathrm{x}}\right]$ by the modification of a published procedure [3]. The complex $\left[\left\{\mathrm{RuCl}_{2}(\mathrm{COD})\right\}_{\mathrm{x}}\right]$, (1.20 g, $\left.4.3 \mathrm{mmol}\right)$ was suspended in methanol $(30 \mathrm{~mL})$ and hydrazine hydrate $(98 \%, 3 \mathrm{~mL})$ was added. The solution obtained on shaking ( $c a .30 \mathrm{~s}$ ) was heated under reflux for $5 \mathrm{~min}$ and the solution was filtered. Addition of a solution of $\mathrm{Na}\left[\mathrm{BPh}_{4}\right](2.5 \mathrm{~g})$ in methanol $(15 \mathrm{~mL})$ and cooling to $0{ }^{\circ} \mathrm{C}$ gave the product as mixtures of colourless prisms and needles containing methanol and water of crystallization. The melting point of the present complex $\left(153-155^{\circ} \mathrm{C}\right)$ is less than that reported for the non-hydrated molecule $\left(160-165{ }^{\circ} \mathrm{C}\right)$ in reference 6 ; this could be as a result of the presence of solvents of crystallization. Yield: 3.21 g, $76 \%$; m.p. $\left({ }^{\circ} \mathrm{C}\right): 153-155$; IR $\left(\mathrm{cm}^{-1}\right)$ : $v(\mathrm{NH}): 3296,3260,3056 \delta(\mathrm{NH})$ : asym 1597, sym $1173 v(\mathrm{NN}): 918 ;{ }^{1} \mathrm{H}$ NMR (dmso, ppm): $1.9-$ 2.2 (br) $\left(\mathrm{NH}_{2}, 8 \mathrm{H}\right), 3.6$ (br) $\left(\mathrm{NH}_{2}, 4 \mathrm{H}\right), 6.7$ (br) $\left(\mathrm{NH}_{2}, 4 \mathrm{H}\right), 4.0-4.2$ (br) $\left(\mathrm{CH}_{2}, 8 \mathrm{H}\right), 5.9$ (br) $(\mathrm{CH}$, $4 \mathrm{H})$, 6.7-7.2 (br) $\left(\mathrm{BPh}_{4}, 20 \mathrm{H}\right)$. Elemental analysis calcd $(\%)$ for $\mathrm{C}_{56} \mathrm{H}_{68} \mathrm{~B}_{2} \mathrm{~N}_{8} \mathrm{Ru} \cdot \mathrm{CH}_{3} \mathrm{OH} \cdot \mathrm{H}_{2} \mathrm{O}: \mathrm{C}$ 66.73, H 7.23, N 10.93; found: C 66.49, H 7.10, N, 11.13.

Bis(acetone hydrazone)tetrakis(benzyl isocyanide)ruthenium(II) bis(tetraphenylborate) (3)

An acetone solution $(20 \mathrm{~mL})$ of $2(0.20 \mathrm{~g}, 0.2 \mathrm{mmol})$ and benzyl isocyanide $(0.15 \mathrm{~mL}, 1.21$ mmol) was heated under reflux for $19 \mathrm{~h}$. Ethanol $(10 \mathrm{~mL})$ was then added to the pale yellow solution and the acetone was removed under reduced pressure and a white precipitate formed. The product was filtered and recrystallized from acetone and ethanol as colorless needles. Yield: 0.18 g, 68\%; m.p.: decomp > $200{ }^{\circ} \mathrm{C}$; IR $\left(\mathrm{cm}^{-1}\right): v(\mathrm{NH}): 3271,3220, v(\mathrm{CN}): 2172 ;{ }^{1} \mathrm{H}$ NMR 
$\left(\mathrm{CDCl}_{3}, \mathrm{ppm}\right): 1.80(\mathrm{~s})$ and 1.85(s) (azomethine $\left.\mathrm{CH}_{3}\right), 5.29(\mathrm{~s})\left(\mathrm{NH}_{2}\right)$ 2.87(s) $\left(\mathrm{CH}_{2}\right), 6.78-7.46$ (phenyl protons); elemental analysis calcd (\%) for $\mathrm{C}_{86} \mathrm{H}_{84} \mathrm{~B}_{2} \mathrm{~N}_{2} \mathrm{Ru}$ : C 76.39, H 6.22, N 8.29; found: C 76.51, H 6.01, N 8.23.

\section{Structure solution and refinement of compounds $\mathbf{2}$ and $\mathbf{3}$}

The crystal structure determination of compounds $\mathbf{2}$ and $\mathbf{3}$ were carried out using a Bruker SMART APEX2 CCD-based X-ray diffractometer equipped with a low-temperature device and Mo-target X-ray tube (wavelength $=0.71073 \AA$ ). The X-ray data were collected at $100(2) \mathrm{K}$. Data collection, indexing, and initial cell refinements were carried out using APEX2 [13], with the frame integrations and final cell refinements carried out using SAINT [14]. Absorption corrections were applied using SADABS [15], and all non-hydrogen atoms were refined anisotropically. Hydrogen atoms of the $\mathrm{NH}_{2}$ moieties in compound $\mathbf{3}$ were located from the difference Fourier map and refined isotropically. The remaining hydrogen atoms were placed in idealized positions and were refined using a riding model. The structures were solved and refined using the SHELXTL program package software [16]. Refinement details and structural parameters for compounds $\mathbf{2}$ and $\mathbf{3}$ are summarized in Table 1. One phenyl ring from a $\mathrm{BPh}_{4}$ moiety in compound 2 was modelled disordered over two positions in a 68:32 ratio. The $\mathrm{Ru}$ atom was also modelled as disordered over two positions in a 89:11 ratio.

Table 1. Crystal data and structure refinement for complexes $\mathbf{2}$ and $\mathbf{3 .}$

\begin{tabular}{|c|c|c|}
\hline & 2 & 3 \\
\hline Crystal system & Monoclinic & Monoclinic \\
\hline Space group & $\mathrm{P} 2{ }_{1} / c$ & $\mathrm{P} 2{ }_{1} / n$ \\
\hline $\mathrm{a}, \AA$ & $17.711(5)$ & $13.4108(17)$ \\
\hline $\mathrm{b}, \AA$ & $11.518(5)$ & $19.156(2)$ \\
\hline $\mathrm{c}, \AA$ & $24.886(5)$ & $14.2231(18)$ \\
\hline$\beta$, deg & $91.739(5)$ & $104.353(2)$ \\
\hline $\mathrm{V}, \AA^{3}$ & $5074(3)$ & $3539.8(8)$ \\
\hline Empirical formula & $\mathrm{C}_{114} \mathrm{H}_{145} \mathrm{~B}_{4} \mathrm{~N}_{16} \mathrm{O}_{4} \mathrm{Ru}_{2}$ & $\mathrm{C}_{86} \mathrm{H}_{84} \mathrm{~B}_{2} \mathrm{~N}_{8} \mathrm{Ru}$ \\
\hline Formula weight & 2048.84 & 1352.30 \\
\hline formula units per cell $(\mathrm{Z})$ & 2 & 2 \\
\hline $\mathrm{D}_{\text {calcd }}\left(\mathrm{Mg} / \mathrm{m}^{3}\right)$ & 1.341 & 1.269 \\
\hline$\lambda(\mathrm{Mo} \mathrm{K} \alpha), \AA$ & 0.71069 & 0.71073 \\
\hline$\mu\left(\mathrm{mm}^{-1}\right)$ & 0.361 & 0.274 \\
\hline Absorption correction & Semi-empirical from equivalents & Semi-empirical from equivalents \\
\hline Total reflections & 129287 & 42372 \\
\hline Independent reflections & 12816 & 7793 \\
\hline $\mathrm{R}_{\text {int }}$ & 0.1123 & 0.0370 \\
\hline Data/restraints/parameters & $12816 / 49 / 685$ & $7793 / 0 / 449$ \\
\hline $\mathrm{R} 1[\mathrm{I} \geq 2 \sigma(\mathrm{I})]$ & 0.0561 & 0.0282 \\
\hline$w \mathrm{R} 2$ (all data) & 0.1609 & 0.0733 \\
\hline GOF on $\mathrm{F}^{2}$ & 1.042 & 1.019 \\
\hline$\Delta \rho(\max ), \Delta \rho(\min )\left(\mathrm{e} / \AA^{3}\right)$ & 0.896 and -0.645 & 0.374 and -0.395 \\
\hline
\end{tabular}




\section{RESULTS AND DISCUSSION}

\section{The hydrazine complex}

Stirring a suspension of $\left[\left\{\mathrm{RuCl}_{2}(\mathrm{COD})\right\}_{\mathrm{x}}\right](\mathbf{1})$ in boiling methanol under reflux for 5 min with hydrazine hydrate rapidly resulted in a pale red solution from which the salt $\left[\mathrm{Ru}(\mathrm{COD})\left(\mathrm{N}_{2} \mathrm{H}_{4}\right)_{4}\right]\left[\left(\mathrm{BPh}_{4}\right)_{2}\right] \cdot \mathrm{CH}_{3} \mathrm{OH}$ (Figure 1) was isolated in high yield on addition of a methanolic solution of $\mathrm{Na}\left[\mathrm{BPh}_{4}\right]$ (equation 1). Thus, it is not necessary to use anhydrous hydrazine to prepare complex $\mathbf{2}$, as described in the earlier reports.
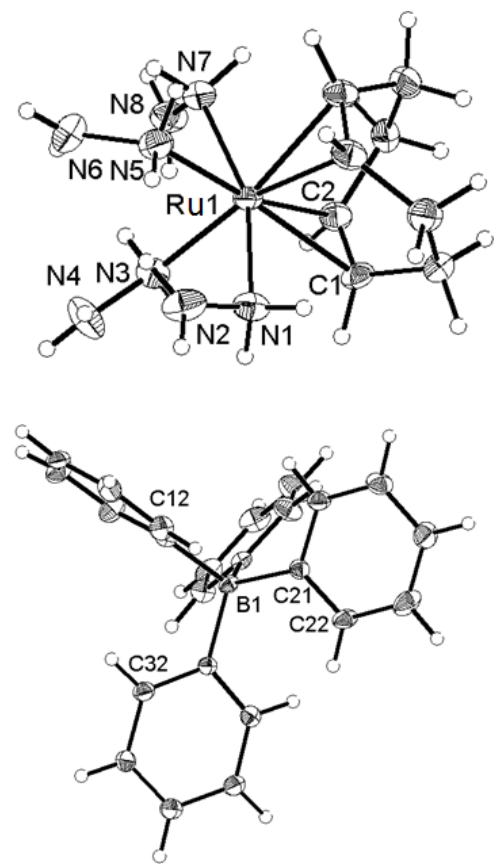

Figure 1. Molecular diagram for $\left[\mathrm{Ru}(\mathrm{COD})\left(\mathrm{H}_{2} \mathrm{NNH}_{2}\right)_{4}\right]\left[\mathrm{BPh}_{4}\right]_{2}$ with ellipsoids representing a displacement probability of $50 \%$. For the $\mathrm{BPh}_{4}$, all rings are numbered systematically, with the first number representing the ring number and the second number representing the atom number. Only one of the $\mathrm{BPh}_{4}{ }^{-}$anion is shown while the molecules of solvation are removed for clarity.

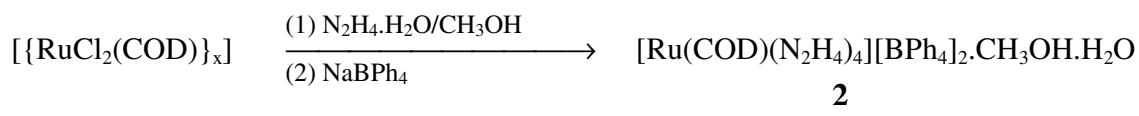

Tetraphenylborate was the only counter anion that effected precipitation and attempts to isolate the cations of 2 with other anions such as $\left[\mathrm{BF}_{4}\right]^{-}$and $\left[\mathrm{PF}_{6}\right]^{-}$were not successful, consistent with earlier reports [3]. Complex 2 is stable in air and light for a period of six weeks after which slow decomposition starts to occur. It is soluble in solvents such as dimethyl sulphoxide (DMSO), acetone and dimethylformamide but not soluble in ethanol, methanol, dichloromethane and other common organic solvents. 
Suitable crystals of $\mathbf{2}$ were grown from hydrazine hydrate/methanol mixture. The compound crystallizes in the monoclinic space group $\mathrm{P} 2{ }_{1} / c$ with the unit cell dimensions $a=17.711, b=$ 11.518 and $c=24.886 \AA$. A molecular diagram showing the numbering scheme of the compound $\left[\mathrm{Ru}(\mathrm{COD})\left(\mathrm{H}_{2} \mathrm{NNH}_{2}\right)_{4}\right]\left[\mathrm{BPh}_{4}\right]_{2} \bullet \mathrm{MeOH} \bullet \mathrm{H}_{2} \mathrm{O}, \mathbf{2}$, is presented in Figure 1, with selected bond lengths and angles in Table 2 . The $\mathrm{Ru}$ (II) metal center is octahedrally coordinated to the cyclooctadiene ligand and four $\mathrm{H}_{2} \mathrm{NNH}_{2}$ ligands. The angles around the $\mathrm{Ru}$ (II) atom are all close to $90^{\circ}$, in accordance with a distorted octahedral coordination sphere. The COD ligand adopts the usual boat or tub conformation with the four doubly bonded $\mathrm{C}$ atoms having an average bond distance of $2.208 \AA$ which is slightly longer than bonding distance of Ru (2.14-2.19) [17]. An average $\mathrm{Ru}(\mathrm{II})-\mathrm{NH}_{2}$ bond distance of $2.15 \AA$ was observed, slightly longer than in compound 3. An average $\mathrm{N}-\mathrm{N}$ distance of $1.45 \AA$ was observed. The $\mathrm{Ru}(\mathrm{II})-\mathrm{N}-\mathrm{N}$ angles were found to be $114^{\circ}$ on average. These values are all comparable to those of compound 3 . No special features were observed for the tetraphenylborate anions. A molecule of methanol as well as a hydrate was observed in the asymmetric unit of $\mathbf{2}$.

Table 2. Selected bond lengths $[\AA]$ and angles $\left[{ }^{\circ}\right]$ for compounds $\mathbf{2}$ and $\mathbf{3}$.

\begin{tabular}{|c|c|c|c|}
\hline \multicolumn{2}{|c|}{$\mathbf{2}$} & \multicolumn{2}{|c|}{$\mathbf{3}$} \\
\hline $\mathrm{Ru}(1 \mathrm{~A})-\mathrm{N}(5)$ & $2.128(3)$ & $\mathrm{Ru}(1)-\mathrm{C}(9 \mathrm{~B})$ & $2.0069(15)$ \\
\hline $\mathrm{Ru}(1 \mathrm{~A})-\mathrm{N}(3)$ & $2.135(3)$ & $\mathrm{Ru}(1)-\mathrm{C}(9)$ & $2.0070(15)$ \\
\hline $\mathrm{Ru}(1 \mathrm{~A})-\mathrm{N}(1)$ & $2.151(3)$ & $\mathrm{Ru}(1)-\mathrm{C}(1 \mathrm{~B})$ & $2.0082(15)$ \\
\hline $\mathrm{Ru}(1 \mathrm{~A})-\mathrm{N}(7)$ & $2.179(3)$ & $\mathrm{Ru}(1)-\mathrm{C}(1)$ & $2.0083(15)$ \\
\hline $\mathrm{Ru}(1 \mathrm{~A})-\mathrm{C}(1)$ & $2.204(4)$ & $\mathrm{Ru}(1)-\mathrm{N}(3 \mathrm{~A})$ & $2.1416(13)$ \\
\hline $\mathrm{Ru}(1 \mathrm{~A})-\mathrm{C}(2)$ & $2.205(4)$ & $\mathrm{Ru}(1)-\mathrm{N}(3)$ & $2.1416(13)$ \\
\hline $\mathrm{Ru}(1 \mathrm{~A})-\mathrm{C}(5)$ & $2.206(4)$ & $\mathrm{Ru}(1 \mathrm{~A})-\mathrm{C}(6)$ & $2.215(4)$ \\
\hline \multicolumn{4}{|c|}{$\mathrm{Angles}$} \\
$\mathrm{N}(5)-\mathrm{Ru}(1 \mathrm{~A})-\mathrm{N}(3)$ & $94.26(13)$ & $\mathrm{N}(3 \mathrm{~B})-\mathrm{Ru}(1)-\mathrm{N}(3)$ & 180.0 \\
\hline $\mathrm{N}(5)-\mathrm{Ru}(1 \mathrm{~A})-\mathrm{N}(1)$ & $85.62(14)$ & $\mathrm{C}(9 \mathrm{~B})-\mathrm{Ru}(1)-\mathrm{C}(9)$ & $180.0(3)$ \\
\hline $\mathrm{N}(3)-\mathrm{Ru}(1 \mathrm{~A})-\mathrm{N}(1)$ & $84.91(13)$ & $\mathrm{C}(1 \mathrm{~B})-\mathrm{Ru}(1)-\mathrm{C}(1)$ & 180.0 \\
\hline $\mathrm{N}(5)-\mathrm{Ru}(1 \mathrm{~A})-\mathrm{N}(7)$ & $81.53(14)$ & $\mathrm{C}(9 \mathrm{~B})-\mathrm{Ru}(1)-\mathrm{N}(3 \mathrm{~B})$ & $92.65(6)$ \\
\hline $\mathrm{N}(3)-\mathrm{Ru}(1 \mathrm{~A})-\mathrm{N}(7)$ & $82.81(13)$ & $\mathrm{C}(1)-\mathrm{Ru} 1-\mathrm{C}(9)$ & $89.37(6)$ \\
\hline
\end{tabular}

The hydrazone complex

Treatment of 2 with four equivalent of $\mathrm{CNCH}_{2} \mathrm{Ph}$ or $\mathrm{CN}^{t} \mathrm{Bu}$ in boiling acetone under reflux resulted in the formation of the salts $\left[\mathrm{Ru}(\mathrm{CNR})_{4}\left(\mathrm{NH}_{2} \mathrm{~N}: \mathrm{CMe}_{2}\right)_{2}\right]\left[\mathrm{BPh}_{4}\right]_{2}\left(\mathbf{3}, \mathrm{R}=\mathrm{CNCH}_{2} \mathrm{Ph} ; \mathbf{4}, \mathrm{R}\right.$ $=\mathrm{CN}^{t} \mathrm{Bu}$ ) in good yields (equation 2).

$\left[\mathrm{Ru}(\mathrm{COD})\left(\mathrm{N}_{2} \mathrm{H}_{4}\right)_{4}\right]\left[\mathrm{BPh}_{4}\right]_{2} \stackrel{\text { L/acetone }}{\longrightarrow} \quad\left[\mathrm{Ru}\left(\mathrm{NH}_{2} \mathrm{~N}: \mathrm{CMe}_{2}\right)_{2} \mathrm{~L}_{4}\right]\left[\mathrm{BPh}_{4}\right]_{2}$

Various attempts to substitute the ligands in these complexes with other groups such as $\mathrm{CO}$, pyridine and $\mathrm{CO}_{2}$ were not successful.

Suitable crystals of compound $\mathbf{3}$ were grown from a methylene chloride/ethanol mixture in the ratio $1: 4$. The compound crystallizes in the monoclinic space group $\mathrm{P} 2{ }_{1} / n$ with the unit cell dimension $a=13.4108, b=19.156$ and $c=14.2231 \AA$. The molecular diagram showing the numbering scheme for compound $\mathbf{3}$ is presented in Figure 2, with selected bond distances and angles in Table 3 . The two hydrazone ligands are mutually trans to each other and the bonding to the ruthenium atom is through the expected amino $\mathrm{N}$ atoms (Figure 2). The isocyanide ligands are cis to one another and bonded to the ruthenium through the lone pair on the $\mathrm{C}$ atom. 
The $\mathrm{N}-\mathrm{N}$ distance of $1.45 \AA$ in this $\mathrm{Ru}$ cation is shorter than the value of $1.51 \AA$ reported in the literature for $\left[\mathrm{OsCl}(\mathrm{COD})\left(\mathrm{CN}^{t} \mathrm{Bu}\right)\left(\mathrm{NH}_{2} \mathrm{~N}: \mathrm{CMe}_{2}\right)_{2}\right]^{2+}[6]$ but falls within the reported range of 1.45-1.48 $\AA$ [18]. The average $\mathrm{Ru}-\mathrm{NH}_{2}$ distance of $2.14 \AA$ and $\mathrm{Ru}-\mathrm{N}-\mathrm{N}$ angles of $115^{\circ}$ in this complex are rather small when compared with the reported metal- $\mathrm{NH}_{2}$ and metal $-\mathrm{N}-\mathrm{N}$ angles of $2.17 \AA$ and $119^{\circ}$ in $\left[\mathrm{Ru}\left(\mathrm{NH}_{2} \mathrm{~N}: \mathrm{CMe}_{2}\right)_{2}\left\{\mathrm{P}(\mathrm{OMe})_{3}\right\}_{4}\right]^{2+}$ [19]. In the hydrazone complex $\left[\mathrm{W}\left(\eta-\mathrm{C}_{5} \mathrm{H}_{5}\right)(\mathrm{CO})_{3}\left(\mathrm{NH}_{2} \mathrm{~N}: \mathrm{CMe}_{2}\right)_{2}\right]^{2+}$, the metal- $\mathrm{NH}_{2}$ distance is $2.27 \AA$ and the metal $-\mathrm{N}-\mathrm{N}$ angle is $112^{\circ}$. While the variation in the $\mathrm{M}-\mathrm{N}$ distances in these complexes could be attributed to the differences in covalent radii of these metals, the wide variation in their bond angles remain difficult to explain but could be due to crystal packing effects.

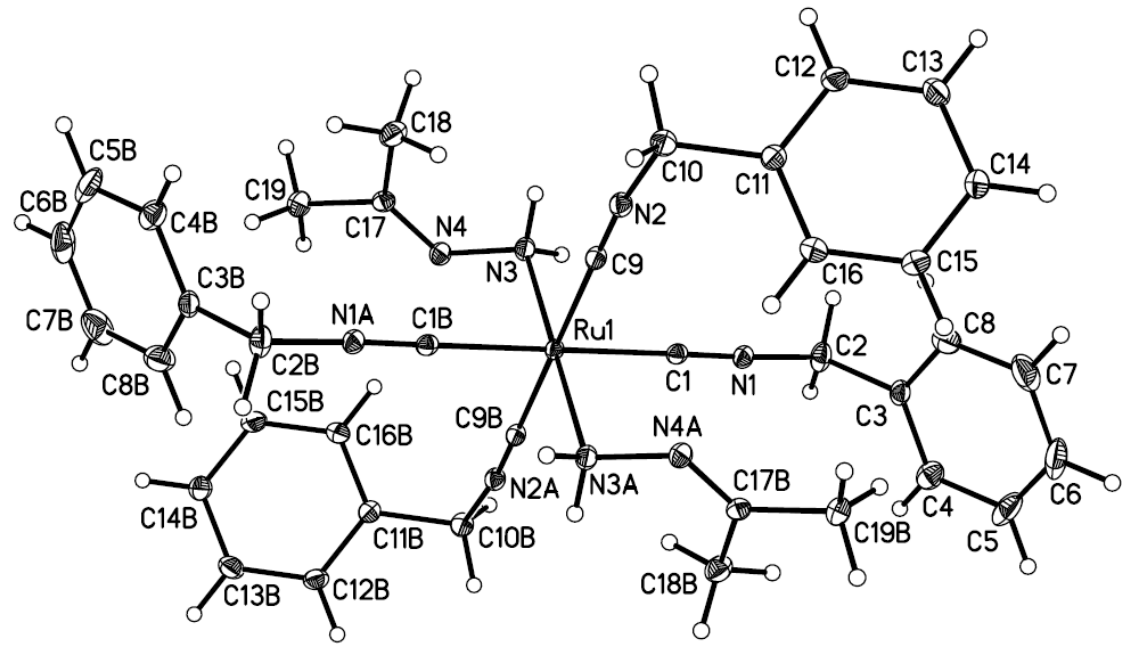

Figure 2. Molecular structure of $\left[\mathrm{Ru}\left(\mathrm{CNCH}_{2} \mathrm{C}_{6} \mathrm{H}_{5}\right)_{4}\left(\mathrm{H}_{2} \mathrm{NNC}:\left(\mathrm{CH}_{3}\right)_{2}\right]^{2+}\right.$ with atom labelling. Thermal ellipsoids are drawn at the $50 \%$ probability level. The $\mathrm{BPh}_{4}{ }^{-}$anions are omitted for clarity.

\section{CONCLUSIONS}

The ruthenium(II) hydrazine complex $\left[\mathrm{Ru}(\mathrm{COD})\left(\mathrm{NH}_{2} \mathrm{NH}_{2}\right)_{4}\right]\left[\mathrm{BPh}_{4}\right]_{2} \cdot \mathrm{CH}_{3} \mathrm{OH}$ has been prepared via simple reaction of the polymeric species $\left[\left\{\mathrm{RuCl}_{2}(\mathrm{COD})\right\}_{\mathrm{x}}\right]$ with hydrazine hydrate in methanol under reflux. Single crystal structure analysis indicates a distorted octahedral geometry with the ruthenium compound ligated by four hydrazine and one COD molecule. The subsequent reaction of the hydrazine salt with benzyl isocyanide in acetone produced the hydrazone complex $\left[\mathrm{Ru}\left(\mathrm{CNCH}_{2} \mathrm{Ph}\right)_{4}\left(\mathrm{NH}_{2} \mathrm{~N}: \mathrm{CMe}_{2}\right)_{2}\right]\left[\mathrm{BPh}_{4}\right]$.

\section{ACKNOWLEDGEMENTS}

The $\mathrm{Ru}-\mathrm{NH}_{4}$ salt used was a gift from Impala Platinum Pty Ltd, South Africa to NJC. Financial support from University of the Witwatersrand and the NRF is gratefully acknowledged and Samson O. Owalude is grateful to the University of Ilorin for a Staff Development Award grant to undertake this study. Dr. B. Owaga and Mr. L. Kirsten are thanked for discussions on the crystallography of compound $\mathbf{2}$. 


\section{SUPPLEMENTARY MATERIAL}

CCDC 865653 and 860358 contains the crystallographic data for the structures have been deposited with the Cambridge Crystallographic Data Centre. Copies of the data can be obtained free of charge on application to the Director, CCDC, 12 Union Road, Cambridge CB2 1EZ, UK (e-mail for deposition: deposit@ ccdc.cam.ac.uk).

\section{REFERENCES}

1. (a) Alvarez, P.; Gimeno, J.; Lastra, E.; Garcı-Granda, S.; Van der Maelen, J.F.; Bassetti, M. Organometallics 2001, 20, 3762. (b) Esteruelas, M.A.; Oro, L.A. Coord. Chem. Rev. 1999, 557, 193.

2. (a) Albers, M.O.; Francesca, S.; Crosby, A.; Liles, D.C.; Robinson, D.J.; Shaver, A.; Singleton, E. Organometallics 1987, 6, 2014. (b) Gemel, C.; Trimmel, G.; Slugvoc, C.; Kremel, S.; Mereiter, K.; Schmid, R.; Kirchner, K. Organometallics 1996, 15, 3998.

3. Ashworth, T.V.; Singleton, E.; Hough, J.J. J. Chem. Soc, Dalton Trans. 1977, 1809.

4. Albers, M.O.; Ashworth, T.V.; Oosthuizen, H.E.; Singleton, E.; Merola, J.S.; Kacmarcik, R.T. Inorg. Synth. 1989, 26, 68.

5. Pérez-Torrente, J.J.; Cunchillos, C.; Gómez-Bautista, D.; Jiménez, M.V.; Castarlenas, R.; Lahoz, F.J.; Oro, L.A. J. Coord. Chem. 2012, 65, 2981.

6. Oosthuizen, H.E.; Singleton, E.; Field, J.S.; Van Niekerk, G.C. J. Organomet. Chem. 1985, $279,433$.

7. Kisch, H.; Holzmeier, P. Adv. Organomet. Chem. 1992, 34, 67.

8. Sutton, D. Chem. Rev. 1993, 93, 995.

9. Albertin, G.; Antoniutti, S.; Castro, J. J. Organomet. Chem. 2012, 697, 6.

10. Heaton, B.T.; Jacob, C.; Page, P. Coord. Chem. Rev. 1996, 154, 193.

11. Dabb, S.L.; Messerle, B.A.; Otting, G.; Wagler, J.; Willis, A. Chem. Eur. J. 2008, 14, 10058.

12. Singleton, E.; Swanepoel, H.E. Inorg. Chim. Acta 1982, 57, 217.

13. Bruker APEX2; Bruker Advanced Analytical X-ray Systems, Inc. Copyright 2007, Madison, WI

14. Bruker Saint; Bruker Advanced Analytical X-ray Systems, Inc. Copyright 2007, Madison, WI.

15. Bruker SADABS; Bruker Advanced Analytical X-ray Systems, Inc. Copyright 2007, Madison, WI.

16. SHELXTL Version 6.14, Bruker Advanced Analytical X-ray Systems, Inc. Copyright 2003, Madison, WI.

17. Ashworth, T.V.; Nolte, M.J.; Singleton, E. J. Chem. Soc, Dalton Trans. 1978, 1040.

18. Bottomley, F. Q. Rev. Chem. Soc. 1970, 24, 617.

19. Nolte, M.J; Singleton, E. J. Chem. Soc., Dalton Trans. 1974, 2406. 